\title{
Design and Implementation of Mobile Application for Results Dissemination System
}

\section{Mukarukundo Josette}

Faculty of Education, Department of Didactic, Option of Computer Science and Mathematic, Catholic University of Rwanda, Butare, Rwanda

Email: josettemukarukundo@gmail.com,rukojo@gmail.com

How to cite this paper: Josette, M. (2017) Design and Implementation of Mobile Application for Results Dissemination System. Journal of Software Engineering and Applications, 10, 787-791. https://doi.org/10.4236/jsea.2017.109044

Received: May 3, 2017

Accepted: August 25, 2017

Published: August 28, 2017

Copyright $\odot 2017$ by author and Scientific Research Publishing Inc. This work is licensed under the Creative Commons Attribution International License (CC BY 4.0).

http://creativecommons.org/licenses/by/4.0/

\begin{abstract}
Mobile application is a kind of an application system delivered via on mobile phone, it is basically network-enabled convey of skills and knowledge. Due to advanced technology of smart phones, this application has become an important system that facilitates a large amount of people to access the information efficiently. The aim of this research is to design and implement a mobile application which is able to disseminate student's results of their exams. We have developed this application with Java Programming Language, Phased model as Software Development methodology and Android technology [1]. This research has used following methods in terms of collecting data; This research has used following methods in terms of collecting data: documentation, interview and observation techniques. The researcher has concluded that the system has been successfully implemented using Phased Model Methodology.
\end{abstract}

\section{Keywords}

Mobile Application for Results Dissemination System, Android, Java, Smart Phone, Phased Model

\section{Introduction}

Mobile application for results dissemination is a needed system in higher learning institutions in order to deliver students' marks in easy way. The purpose of mobile application is to strengthen the quality of services delivered by higher learning institution. This is software which was designed by using Unified Modeling Language diagrams and implemented by using software development methodology, especially phased model through to the phases of conception: plan- 
ning and selection, requirement analysis, system design, implementation of the system, system testing, operations \& maintenance [2] [3]. The research purpose is to design and implement a mobile application system which will help Catholic University of Rwanda to disseminate the results. This will facilitate the student's access to their results using their mobile phones.

\section{Planning and Selection}

This is a first stage of software development methodology that focuses on feasibility study [4].

\subsection{Feasibility Study}

The following are the concepts of feasibility study: Economic, Financial, Operational, Technical, Legal and Political.

\subsubsection{Economic Feasibility}

There are benefits from Design and Implementation of Mobile Application for Results Dissemination System due to good quality of services.

\subsubsection{Financial Feasibility}

The Catholic University of Rwanda has contributed to design and implement this application.

\subsubsection{Operational Feasibility}

Observing and evaluating the tickets that are spent by students when they come to pick their transcripts, this system has resolved this issue.

\subsubsection{Technical Feasibility}

The System has been achieved its goals and implemented successful through the knowledge we has in information Technology.

\subsubsection{Legal and Political}

Mobile application for Results Dissemination has been implemented basing on ICT Policy and Ethical and gender consideration.

\section{System Requirements Analysis}

The system requirements analysis is the second phase of software development methodology [4] [5]. Requirements analysis is very important because it describes the needs of the system and shows entities relationship. The requirements are categorized into functional and technical.

\subsection{Functional Requirements Analysis}

Mobile Application for Results Dissemination System has three sets of functions. The first set of functions Mobile Application for Results Dissemination functions that allow the students to login, access their results using mobile phone and claim when there is a mistake then logout and also allows the staffs to login, 
upload the marks and logout.

The second set of functions is system administration that allows the system administrator to manage the database of the system, update it and maintain it, create users and give their privileges for accessing the system.

\section{Operation Flow Chart}

The figure describes the second set of functions. It shows in details what admininistrator does on the system.

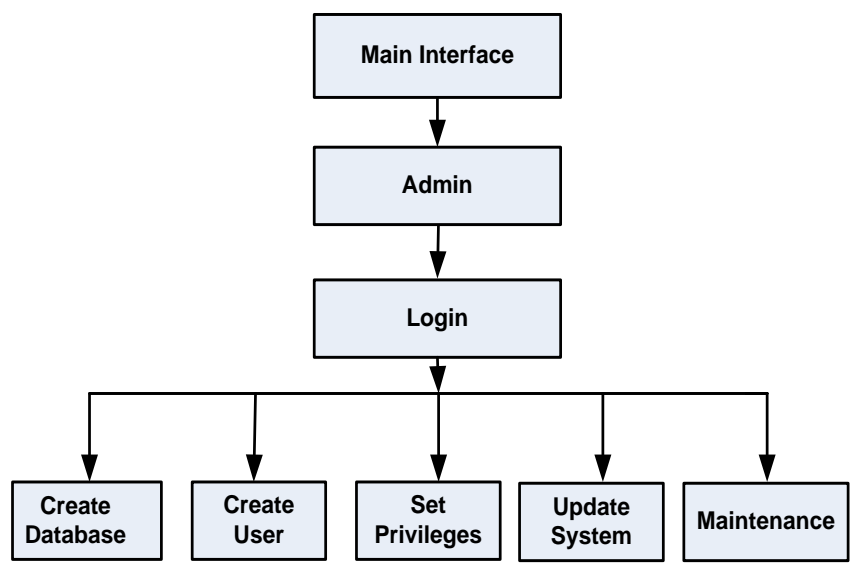

\subsection{Technical Requirements Analysis}

The Network architecture is a client/server based on Windows clients running with Windows Eight, Web Server, and Web browser. Java programming language development environment, Net Bean as development platform and development tools, SQL server as the database management system.

\section{System Design}

The system is divided into two major components. One is the registration program which presents interfaces to the user, the second is the student program which presents interfaces to the user and the third component is the application server which processes the user's request before it can send response. This application server handles all requests made by the users [5].

\subsection{Use Case Diagram}

User case diagram is describing the users of the system and their roles on System.

In this Application there are three users: Admin, Staff and Student. The use case technique is used to capture a system's behavioral requirements by detailing scenario-driven threads through the functional requirements. Here below is the use case diagram that shows the functionalities of the system.

\subsection{Class Diagram}

In this system, class diagram illustrates entities and the relationships between those entities [6] [7]. 


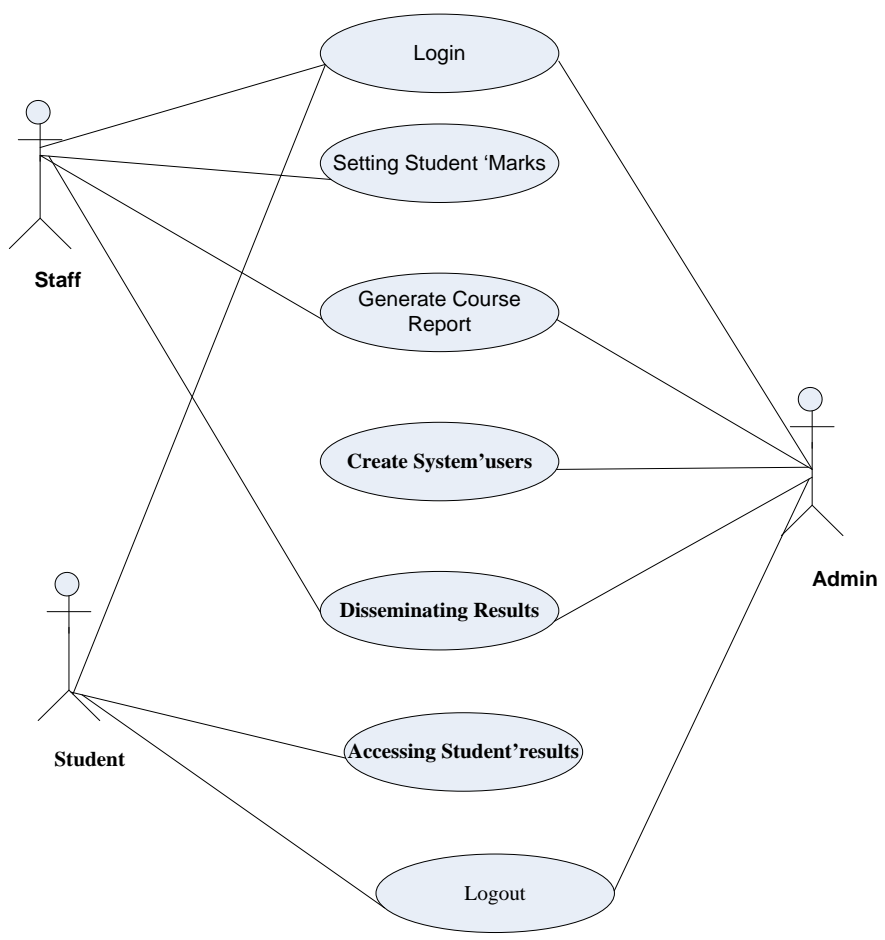

The elements of Class Diagram are entities, relationships, attributes, and the entity-relationship diagram is shown in physical model of data of access global diagram below.

\section{Conclusion}

This research is based on design and implementation of mobile application for results dissemination. The system aims to access student's marks through mobile

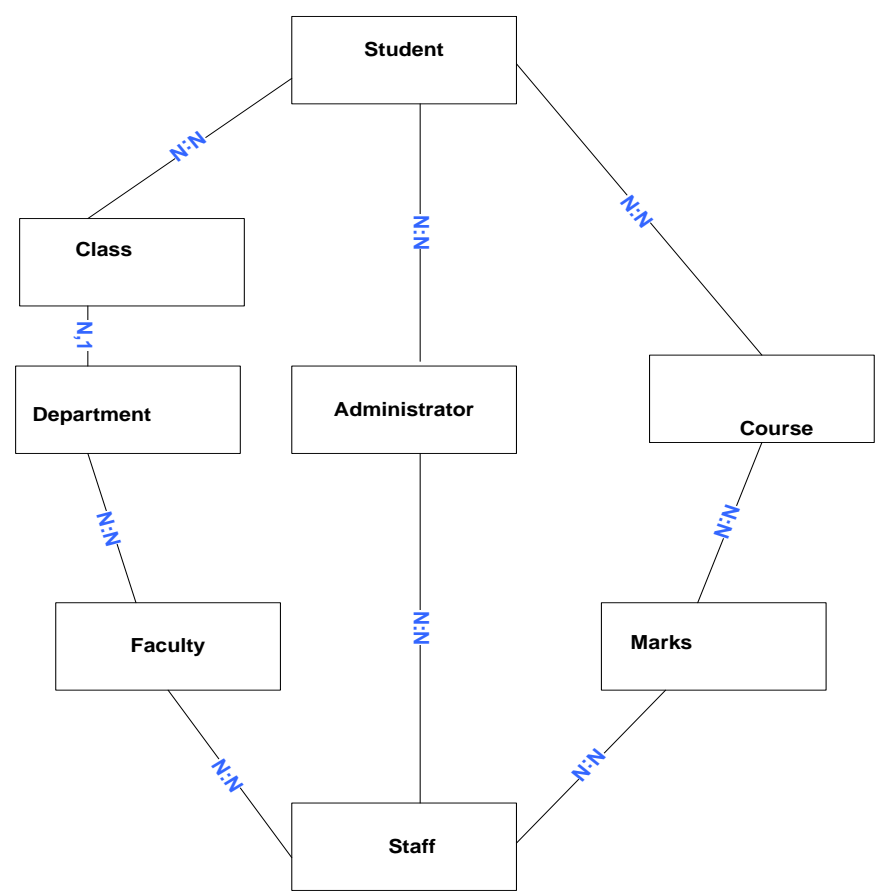


phone. The system has been successfully implemented and delivered services timely and kept data efficiently.

\section{Acknowledgements}

This research was supported by Catholic University of Rwanda, Faculty of Education, Department of Didactics, Option of Computer Science and Mathematics. I also recognize my colleagues who support me in term of sharing ideas.

\section{References}

[1] Lena Trojer, L. (2007) An Interactive E-Learning Management System (E-LMS): A Solution to Tanzanian Secondary Schools' Education. XXI.

[2] He, H. and Yang, J. (2004) Multiresolution Indexing of XML for Frequent Queries. Proceedings of the 20th International Conference on Data Engineering, Boston, 2-2 April 2004, 683-694. https://doi.org/10.1109/ICDE.2004.1320037

[3] Chen, M.S., Wu, K.-L. and Yu, P.S. (2003) Optimizing Index Allocation for Sequential Data Broadcasting in Wireless Mobile Computing. IEEE Transactions on Knowledge and Data Engineering, 15, 161-173. https://doi.org/10.1109/TKDE.2003.1161588

[4] Valacich, J.S., George, J.F. and Hoffer, J.A. (2012) Essentials of Systems Analysis and Design. 5th Edition.

[5] Collier, G. (2002) Learning Application Infrastructure. Sun Microsystems White Paper.

[6] Al-Khalifa, S., Jagadish, H.V., Koudas, N., Patel, J.M., Srivastava, D. and Wu, Y. (2002) Structural Joins: A Primitive for Efficient XML Query Pattern Matching. Proceedings of 18 th International Conference on Data Engineering (ICDE), San Jose, 26 February-1 March 2002, 141-152. https://doi.org/10.1109/ICDE.2002.994704

[7] Kaushik, R., Krishnamurthy, R., Naughton, J.F. and Ramakrishnan, R. (2004) On the Integration of Structure Indexes and Inverted Lists. Proceedings of the 2004 ACM SIGMOD International Conference on Management of Data, Paris, 13-18 June 2004, 779-790. https://doi.org/10.1145/1007568.1007656 
Submit or recommend next manuscript to SCIRP and we will provide best service for you:

Accepting pre-submission inquiries through Email, Facebook, LinkedIn, Twitter, etc. A wide selection of journals (inclusive of 9 subjects, more than 200 journals)

Providing 24-hour high-quality service

User-friendly online submission system

Fair and swift peer-review system

Efficient typesetting and proofreading procedure

Display of the result of downloads and visits, as well as the number of cited articles Maximum dissemination of your research work

Submit your manuscript at: http://papersubmission.scirp.org/

Or contact jsea@scirp.org 